\title{
Electrochemical catalysis investigation into the dynamic coordination properties of a pyridine-substituted [2Fe2S] model complex
}

\author{
Xia Zhang a, b, Tianyong Zhang a, b, c, *, Yanhong Wang a, b, Bin Li a, b, c, *, \\ Guanghui Zhang a, Li Hai a, Shuang Jiang a
}

Keywords: Biomimetic chemistry; [FeFe]-Hydrogenase; Reversible transformation; Hydrogen evolution

\begin{abstract}
A pyridine-substituted diiron dithiolate complex ( $\mu$-dmedt)Fe ${ }_{2}(\mathrm{CO})_{5} \mathrm{Py} \mathbf{1}$ was prepared as a biomimetic model for the active site of [FeFe]-hydrogenase by $\mathrm{CO}$-substitution of all-carbonyl complex $\left(\mu\right.$-dmedt) $\mathrm{Fe}_{2}(\mathrm{CO})_{6}\left[\mathrm{dmedt}=\mathrm{SCH}\left(\mathrm{CH}_{3}\right) \mathrm{CH}\left(\mathrm{CH}_{3}\right) \mathrm{S}\right]$ with pyridine, which has been determined by IR, ${ }^{1} \mathrm{HNMR}$, elemental analysis and X-ray crystallography analysis. Electrochemical and IR investigation of the complex 1 in $\mathrm{MeCN}-\left[\mathrm{NBu}_{4}\right]\left[\mathrm{PF}_{6}\right]$ under $\mathrm{N}_{2}$ and under $\mathrm{CO}$ has demonstrated that the reversible transformation reaction between the complex $\mathbf{1}$ and the acetonitrile-substituted species $\left(\mu\right.$-dmedt) $\mathrm{Fe}_{2}(\mathrm{CO})_{5}\left(\mathrm{NCCH}_{3}\right)$ 2. As in reverse transformation, a
\end{abstract}


pyridine ligand is coordinated to a $\mathrm{Fe}^{\mathrm{I}}$ centre, and can be replaced by a solvent molecule under appropriate conditions, which could mimic the function of the flexible coordination site in the $\mathrm{H}_{2}$ ase enzymes. Electrochemical studies also show complex 1 can catalyze hydrogen evolution from HOAc and aqueous media at $-1.26 \mathrm{~V}$.

\section{Introduction}

Hydrogenase enzymes, which were found in a variety of microorganisms and can efficiently catalyze the reduction of protons to hydrogen, can be classified into [Fe]- $\mathrm{H}_{2}$ ases (Hmd- $\mathrm{H}_{2}$ ases), $[\mathrm{NiFe}]-\mathrm{H}_{2}$ ases and $[\mathrm{FeFe}]-\mathrm{H}_{2}$ ases (H-Cluster). [FeFe]-Hydrogenase is the most important hydrogenases which can reversibly catalyze the reduction of proton to hydrogen with a high efficiency. Inspired by hydrogenase, chemists are interested in studying the biomimetic chemistry of [Fe-Fe]- $\mathrm{H}_{2}$ ases due to its highest and fastest catalytic capability for production of hydrogen among all. To obtain better structural and functional diiron model complexes, good donor ligands, such as [1], cyanide [2], phosphine [3-4], thioether or sulfoxide [5], have been introduced into diiron model complexes. Unfortunately, the potentials for catalytic proton reduction of the corresponding phosphine-substituted model complexes fall in the range of ca.-1.76 to $-2.42 \mathrm{~V}$ [5], which is significantly higher than that found for the natural [FeFe]-hydrogenase (ca.-0.4 V vs. NHE) [6]. Some weak $\sigma$-donating ligands, in particular those with $\mathrm{N}$-donor sites, could greatly reduce the potential gap between the $[\mathrm{FeFe}]$-hydrogenase active site and biomimetic complexes. But synthetic diiron complexes of type $\left[(\mu-\mathrm{pdt}) \mathrm{Fe}_{2}(\mathrm{CO})_{5}(\mathrm{~L})\right](\mathrm{L}=$ ligand, $\mathrm{pdt}=$ propyldithiolate $)$ with loosely bound ligands are inherently unstable [7]. The dynamic exchange between the ligand and donor solvent molecule may on one hand limit their functional studies for proton reduction but on the other hand provide a model that can mimic the function of the flexible coordination site in the $\mathrm{H}_{2}$ ase enzymes. 
Herein, $(\mu$-dmedt $)\left[\mathrm{Fe}(\mathrm{CO})_{3}\right]_{2}(\mathrm{dmedt}=2,3$-butanedithiol) [8] was chosen as the parent complex to synthesize a pyridine mono-substituted [2Fe2S] model complex $\mathbf{1}$, as shown in Scheme 1 . The complex 1 was expected to extend new promising models for structural or functional modification with stability and lower reduction potential. The electrochemical catalytic behavior and dynamic coordination of pyridine in $\mathrm{CH}_{3} \mathrm{CN}$ of complex 1 was investigated. Electrochemical and IR investigation of the complex 1 in $\mathrm{MeCN}-\left[\mathrm{NBu}_{4}\right]\left[\mathrm{PF}_{6}\right]$ under $\mathrm{N}_{2}$ and under $\mathrm{CO}$ has demonstrated that the reversible transformation reaction between the complex $\mathbf{1}$ and the acetonitrile-substituted species $\left(\mu\right.$-dmedt) $\mathrm{Fe}_{2}(\mathrm{CO})_{5}\left(\mathrm{NCCH}_{3}\right)$ 2. As in reverse transformation, a pyridine ligand is coordinated to a $\mathrm{Fe}^{\mathrm{I}}$ centre, and can be replaced by a solvent molecule under appropriate conditions, which could mimic the function of the flexible coordination site in the $\mathrm{H}_{2}$ ase enzymes. The complex 1 catalyzed $\mathrm{H}_{2}$ formation from $\mathrm{HOAc}$ and aqueous media at $-1.26 \mathrm{~V}$ and greatly improved stability under such conditions.

\section{[Scheme 1 inserted here]}

\section{Experiment}

2.1. Materials and instruments: Solvents were dried and distilled prior to use according to the standard methods. Other chemicals were of reagent grade and used without further purification. The compound $\left[(\mu\right.$-dmedt $\left.)\left\{\mathrm{Fe}(\mathrm{CO})_{3}\right\}_{2}\right]$ was prepared according to the literature [8]. Cyclic voltammograms were obtained on a CHI-760E electrochemical analyzer using a three-electrode cell in which a glassy carbon (diameter $3 \mathrm{~mm}$ ) electrode was the working electrode, a saturated $\mathrm{Ag}$ / $\mathrm{AgNO}_{3}$ electrode was the reference electrode, and a platinum wire was the auxiliary electrode. The NMR spectra were measured on a Bruker AVANCE III $400 \mathrm{MHz}$ NMR spectrometer. Solution IR spectra were recorded on a Shimadzu FTIR-8400 spectrometer using $0.1 \mathrm{~mm} \mathrm{KBr}$ sealed cells. Elemental analysis was carried out on a Heraeus CHN-Rapid, fully automatic elemental analyzer with TCD detection, type: TMT CHN, BESTELL-NR 2215001. The single-crystal X-ray diffraction 
data were collected with a Rigaku MM-007 diffractometer equipped with a Saturn 724CCD. Data were collected at $293 \mathrm{~K}$ or $113 \mathrm{~K}$ using a confocal monochromator with Mo-Ka radiation $(\lambda=0.71073 \AA)$. Data collection, reduction and absorption correction were performed with the CRYSTALCLEAR program [9]. Structure was solved by direct methods using the SHELXS-97 program [9] and refined by full-matrix least-squares techniques (SHELXL-97) on $F^{2}$. Details of crystal data, data collections and structure refinements are summarized in Table S1 and Fig. S1-S2.

\subsection{The synthesis of ( $\mu$-dmedt) $\mathrm{Fe}_{2}(\mathrm{CO})_{5} P y($ complex 1$)$ :}

The reaction of $\left[(\mu\right.$-dmedt $\left.)\left\{\mathrm{Fe}(\mathrm{CO})_{3}\right\}_{2}\right] 298 \mathrm{mg}(0.74 \mathrm{mmol})[6]$ with $\mathrm{Me}_{3} \mathrm{NO} 58 \mathrm{mg}(0.76 \mathrm{mmol})$ in $5 \mathrm{~mL} \mathrm{CH}_{3} \mathrm{CN}$ was carried out at $0^{\circ} \mathrm{C}$ for 30 min under an atmosphere of nitrogen, the color turned into black from red. The IR spectrum in $\mathrm{CH}_{3} \mathrm{CN}$ shows $\mathrm{CO}$ absorption bands at 2050, 2041, 1986, 1962 and $1932 \mathrm{~cm}^{-1}$, suggesting the formation of acetonitrile mono-substituted species ( $\mu$ dmedt)Fe ${ }_{2}(\mathrm{CO})_{5}\left(\mathrm{NCCH}_{3}\right)$ [8]. And then pyridine $59 \mathrm{mg}(0.74 \mathrm{mmol})$ was added. After stirring for 6 $\mathrm{h}$ at room temperature under an atmosphere of nitrogen, the solvent was filtered and evaporated under vacuum. The remaining residue was purified by column chromatography on neutral alumina with petroleum ether as elute to give complex $\mathbf{1}$ as a black solid. Dark-red crystals of complex $\mathbf{1}$ were collected by volatilized from hexane at $-5^{\circ} \mathrm{C}$. Yield: $178 \mathrm{mg}(56.1 \%)$. Anal. Calcd. (\%) for $\mathrm{C}_{14} \mathrm{H}_{13} \mathrm{Fe}_{2} \mathrm{NO}_{5} \mathrm{~S}_{2}: \mathrm{C}, 37.28 ; \mathrm{H}, 2.91 ; \mathrm{N}, 3.11$ Found(\%): C, 37.02; H, 2.87; N, 3.02. IR(MeCN, $\left.\mathrm{cm}^{-1}\right): v(\mathrm{CO}) 2046(\mathrm{~s}), 2037(\mathrm{~m}), 1983(\mathrm{~s}), 1961(\mathrm{w}), 1921(\mathrm{~m}) .{ }^{1} \mathrm{HNMR}\left(400 \mathrm{MHz}, \mathrm{CD}_{3} \mathrm{CN}\right): 8.58(\mathrm{~d}$, Py), 7.62(s, Py), 7.23(d, Py), 2.18(s, SCH( $\left.\mathrm{CH}_{3}\right) \mathrm{CH}\left(\mathrm{CH}_{3}\right) \mathrm{S}, 1.88\left(\mathrm{~m}, \mathrm{SCH}\left(\mathrm{CH}_{3}\right) \mathrm{CH}\left(\mathrm{CH}_{3}\right) \mathrm{S}\right), 1.47(\mathrm{~d}$, $\left.\mathrm{SCH}\left(\mathrm{CH}_{3}\right) \mathrm{CH}\left(\mathrm{CH}_{3}\right) \mathrm{S}\right), 1.28\left(\mathrm{~d}, \mathrm{SCH}\left(\mathrm{CH}_{3}\right) \mathrm{CH}\left(\mathrm{CH}_{3}\right) \mathrm{S}\right)$.

\section{Results and discussion}

\subsection{Crystal structure of complex 1}

The crystallographic structure of complex 1 is depicted in Fig. 1. Selected bond lengths and bond angles are tabulated in Table S2. Single-crystal X-ray analysis reveals that the $\left[\mathrm{Fe}_{2} \mathrm{~S}_{2}\right]$ skeleton of 
complex 1 shares the well-known butterfly conformation in which each iron center adopts distorted square-pyramidal coordination geometry. The distinction of bridgehead group on mono-substituted diiron complex model has a slight influence on the $\mathrm{Fe}-\mathrm{Fe}$ distance in comparison with that in $(\mu-$ pdt) $\mathrm{Fe}_{2}(\mathrm{CO})_{5} \mathrm{Py}[10]$. The Fe-Fe bond distance $(2.5326(7) \AA)$ is shorter than that of the same pyridine substituted model complex $(\mu-\mathrm{pdt}) \mathrm{Fe}_{2}(\mathrm{CO})_{5} \mathrm{Py}(2.5342(8) \AA)[10]$. The ligand lies in the apical position rather than the basal position as the pyridine ligand in ( $\mu-\mathrm{pdt}) \mathrm{Fe}_{2}(\mathrm{CO})_{5} \mathrm{Py}$ [9]. The Fe-N bond distance $(2.0212(18) \AA)$ is shorter than that of complex $(\mu-p d t) \mathrm{Fe}_{2}(\mathrm{CO})_{5} \mathrm{Py}(2.029(2) \AA)$. The mean Fe-S distance is $2.236 \AA$ and the average angles of Fe-S-Fe and S-Fe-S are $69.07^{\circ}$ and $79.855^{\circ}$, respectively. Furthermore, the mean Fe-C distance $(1.7842 \AA)$ of the substituted iron atom is shorter than that of the unsubstituted iron atom, revealing the increased strength of back-bonding from Fe to $\mathrm{CO}$ caused by coordination of the ligand. The angle of $\mathrm{Fe}(1)-\mathrm{Fe}(2)-\mathrm{N}(1)$ in complex 1 is much higher than that complex ( $\mu$-pdt) $\mathrm{Fe}_{2}(\mathrm{CO})_{5} \mathrm{Py}$ [7]. Accordingly, the basal coordination environment of pyridine on the $\mathrm{Fe}$ atoms is different from the complex $(\mu-\mathrm{pdt}) \mathrm{Fe}_{2}(\mathrm{CO})_{5} \mathrm{Py}$ and indicates the stronger $\pi$-back-donation from the Fe center to the $\mathrm{N}$ [11].

\section{[Fig. 1 inserted here]}

\subsection{Electrochemistry and IR investigation of reversible CO binding of complexes 1-2}

The electrochemical properties of complex 1 were investigated by cyclic voltammogram $(\mathrm{CV})$ in coordinating solvent $\mathrm{CH}_{3} \mathrm{CN}$ in the presence of $\mathrm{Bu}_{4} \mathrm{NPF}_{6}$ as supporting electrolyte. The current response of the redox events at $-1.26 \mathrm{~V}$ and $-1.76 \mathrm{~V}$ versus $\mathrm{Ag} / \mathrm{AgNO}_{3}$ show a linear dependence on the square root of the scan rate, which is an indicative of a diffusion-controlled process, with the electrochemically active species freely diffusing in the $\mathrm{CH}_{3} \mathrm{CN}$ solution under $\mathrm{N}_{2}$ (Fig. S3). For further examination of the electrochemistry of the complex 1 under $\mathrm{CO}$ atmosphere, the reactivity of complex 1 with $\mathrm{CO}$ has been considered [12-13]. The FTIR-spectrum of complex $\mathbf{1}$ in $\mathrm{CH}_{2} \mathrm{Cl}_{2}$ solution under $\mathrm{CO}$ atmosphere and under $\mathrm{N}_{2}$ atmosphere showed complex 1 is stable, Fig. S4. On 
the other hand, compared the CV of complex 1 and corresponding all-carbonyl complex $[(\mu-\mathrm{dmedt})$ $\left.\left\{\mathrm{Fe}(\mathrm{CO})_{3}\right\}_{2}\right]$ in $\mathrm{CH}_{3} \mathrm{CN}$ solution under $\mathrm{CO}$ atmosphere, the $\mathrm{CV}$ of all-carbonyl complex [( $\mu$-dmedt) $\left.\left\{\mathrm{Fe}(\mathrm{CO})_{3}\right\}_{2}\right]$ in $\mathrm{CH}_{3} \mathrm{CN}$ solution under $\mathrm{CO}$ atmosphere displayed a quasi-reversible reduction event at $-1.72 \mathrm{~V}$ (Fig. S5) and the CV of complex 1 showed a reduction peak at $-1.26 \mathrm{~V}$ (Fig. 2A). In summary, complex 1 showed no reactivity with $\mathrm{CO}$ under $\mathrm{CO}$ atmosphere. Furthermore the study of complex 1 under $\mathrm{N}_{2}$ and $\mathrm{CO}$ atmosphere is shown in Fig. 2, reversible transformation between complex 1 and 2 can be observed by $\mathrm{CV}$. In $\mathrm{CH}_{3} \mathrm{CN}$ solution (under $\mathrm{CO}$ atmosphere) a reduction peak was observed at $-1.26 \mathrm{~V}$ (Fig. 2A), which belongs to complex 1 . The deductive potentials of the complex 2 are $400-500 \mathrm{mV}$ more positive than $(\mu-\mathrm{pdt}) \mathrm{Fe}_{2}(\mathrm{CO})_{6}[7]$ and $\left[(\mu\right.$-dmedt $\left.)\left\{\mathrm{Fe}(\mathrm{CO})_{3}\right\}_{2}\right]$, and close to the complex ( $\mu$-pdt) $\mathrm{Fe}_{2}(\mathrm{CO})_{5} \mathrm{Py}[10]$. The electrochemical behavior conveys a message that, although the average electron density of the diiron centers of complex $\mathbf{1}$ is comparable to ( $\mu$ pdt $) \mathrm{Fe}_{2}(\mathrm{CO})_{6}[10]$ and $\left[(\mu\right.$-dmedt $\left.)\left\{\mathrm{Fe}(\mathrm{CO})_{3}\right\}_{2}\right]$, the $\pi$-orbits of the pyridine ring can render the uneven electron density of the two iron atoms through an electron delocalization. The strongaccepting capability, also reported in the complex ( $\mu$-pdt)Fe $\mathrm{Fe}_{2}(\mathrm{CO})_{5} \mathrm{Py}[10]$, suggests pyridine rings has the potential candidates to tune the electron properties of the diiron centers. This can be supported by another evidence that the carbene disubstituted complex $\left((\mu\right.$-dmedt $)\left[\mathrm{Fe}_{2}(\mathrm{CO})_{5}\right] \mathrm{IMe}$, $\mathrm{IMe}=1,3$-dimethylimidazol-2-ylidene) displays similar reductive behaviors to those of the monosubstituents [14]. Then, $\mathrm{CO}$ was removed by continuously $\mathrm{N}_{2}$ for $5 \mathrm{~min}$, a new reduction peak was observed at $-1.76 \mathrm{~V}$ (Fig. $2 \mathrm{~B}$ ) in $\mathrm{CH}_{3} \mathrm{CN}$ solution with the presence of $\mathrm{N}_{2}$, which implied the formation of $\left(\mu\right.$-dmedt)Fe $2(\mathrm{CO})_{5}\left(\mathrm{NCCH}_{3}\right)$ by replacement of $\mathrm{CH}_{3} \mathrm{CN}$ molecules. After continuous ventilation with nitrogen for two hours, only a reduction peak can be observed at $-1.76 \mathrm{~V}$ (Fig. 2C), which implied the complex 1 was disappeared and generation of ( $\mu$-dmedt)Fe ${ }_{2}(\mathrm{CO})_{5}\left(\mathrm{NCCH}_{3}\right)$ [8]. Next, removing $\mathrm{N}_{2}$ by $\mathrm{CO}$ and addition of excess pyridine, the peak of complex 1 at $-1.26 \mathrm{~V}$ was recovered and the peak at $-1.76 \mathrm{~V}$ disappeared (Fig. 2D), which implied the generation of complex 
1 by immediate replacement of $\mathrm{CH}_{3} \mathrm{CN}$ molecules by pyridine molecules. According to the relevant literatures [15-16], $\mathrm{CH}_{2} \mathrm{Cl}_{2}$ solution is used as a non-coordinate solvent for the most [Fe-Fe]- $\mathrm{H}_{2}$ ases mimics. Hence, we studied the electrochemistry of complex 1 in $\mathrm{CH}_{2} \mathrm{Cl}_{2}$ under $\mathrm{CO}$ atmosphere and under $\mathrm{N}_{2}$ atmosphere. As shown in Fig. S6, by switching the atmosphere from $\mathrm{N}_{2}$ to $\mathrm{CO}$, complex 1 both showed a reductive event at $-1.28 \mathrm{~V}$ in $\mathrm{CH}_{2} \mathrm{Cl}_{2}$ either under $\mathrm{CO}$ atmosphere or under $\mathrm{N}_{2}$ atmosphere, coincident with the FTIR-spectrum of complex 1 in $\mathrm{CH}_{2} \mathrm{Cl}_{2}$ solution. This suggests that introduction of a pyridine ligand by $\mathrm{CO}$-substitution of parent complex $\left[(\mu\right.$-dmedt $\left.)\left\{\mathrm{Fe}(\mathrm{CO})_{3}\right\}_{2}\right]$ can diminish the overpotential for proton reduction, which would have higher electrocatalytic efficiency for proton reduction than parent complex $\left(\mu\right.$-pdt) $\mathrm{Fe}_{2}(\mathrm{CO})_{6}[7],\left[(\mu-\mathrm{dmedt})\left\{\mathrm{Fe}(\mathrm{CO})_{3}\right\}_{2}\right]$ and other hydrogenase mimics complexes [15-16].

\section{[Fig. 2 inserted here]}

Further proofs of this hypothesis as well as structural information on the reduced species were sought from FTIR-spectrum. The spectral changes are consistent with the formation of the respective complex $\mathbf{1}$ and $\mathbf{2}$. Reversible transformation between complex $\mathbf{1}$ and $\mathbf{2}$ can also be observed. As shown in Fig. 3A, complex 1 was really stable under $\mathrm{CO}$ atmosphere in $\mathrm{CH}_{3} \mathrm{CN}$ solution. When exposed to $\mathrm{N}_{2}$, complex 1 slowly rearranges to ( $\mu$-dmedt)Fe ${ }_{2}(\mathrm{CO})_{5}\left(\mathrm{NCCH}_{3}\right)$ [8] by replacement one $\mathrm{CO}$ ligand with $\mathrm{CH}_{3} \mathrm{CN}$ molecules, complex 1 was completely converted to complex 2 after two hours of exposure to $\mathrm{N}_{2}$ in $\mathrm{CH}_{3} \mathrm{CN}$ solution (Fig. 3B and 3C). Next, removing $\mathrm{N}_{2}$ by $\mathrm{CO}$ and addition of excess pyridine, ( $\mu$-dmedt) $\mathrm{Fe}_{2}(\mathrm{CO})_{5}\left(\mathrm{NCCH}_{3}\right)$ [8] was readily converted into complex 1 within $5 \mathrm{~min}$ in the presence of CO (Fig. 3D).

\section{[Fig. 3 inserted here]}

Noteworthy is that in $\mathrm{CH}_{3} \mathrm{CN}$ under $\mathrm{CO}$ atmosphere, the conversion from complex $\mathbf{1}$ to ( $\mu$ dmedt)Fe $\mathrm{Fe}_{2}(\mathrm{CO})_{5}\left(\mathrm{NCCH}_{3}\right)$ [8] could not happen, which proved the complex $\mathbf{1}$ is more stable than the previous complex ( $\mu$-pdt) $\mathrm{Fe}_{2}(\mathrm{CO})_{5}\left(\mathrm{NH}_{2} \mathrm{Pr}\right)$ [8]. When the complex 1 exposed to $\mathrm{N}_{2}$ atmosphere in 
$\mathrm{CH}_{3} \mathrm{CN}$ solution, the conversion from complex 1 to 2 went to completion within $2 \mathrm{~h}$, which was considerably slower than the previous reports [8]. These experiments show that reversible carbonylation of model complexes is affected not only by the nature of pendant ligated ligand but also the type of bridging thiolate ligand. The $[2 \mathrm{Fe} 2 \mathrm{~S}]$ model complexes of type $[(\mu-$ dmedt $\left.)_{F_{2}}(\mathrm{CO})_{5}(\mathrm{~L})\right](\mathrm{L}=$ ligand, $\mathrm{pdt}=$ 2,3-butanedithiol $)$ are more stable and require lower reduction potential than previous reports [8].

\subsection{Electrochemical proton reduction investigation}

To determine possible electrocatalytic activity of complex $\mathbf{1}$, the electrocatalytic property towards $\mathrm{H}_{2}$ development of complex 1 was carried out in the presence of HOAc in MeCN. The electrochemical behavior of complex 1 was analyzed in details in the presence of HOAc $(0-8$ mmol) as a source of protons (Fig. 4). Upon addition of $1 \mathrm{mmol}$ of HOAc to the complex 1, the first reductive peak for complex $\mathbf{1}$ at $-1.26 \mathrm{~V}$ did not shift and the current height showed a minor growing, indicating that $\mathrm{H}^{+}$did not incorporate to the model complex 1. Interestingly, with the upon addition of HOAc $(0-8 \mathrm{mmol})$, an increase in the current of this second cathodes wave was observed, with these shifts continuing with each increment of acid added thereafter, the second peak at $-1.76 \mathrm{~V}$ (which belongs to the complex 2 ) was shifted towards a more negative potential at -1.81 $\mathrm{V}$ when detected under $\mathrm{N}_{2}$ [17-20]. It is tentatively proposed that any hydrogen evolution occurs from the $\mathrm{Fe}^{0} \mathrm{Fe}^{0}$ redox state. The electrochemical behavior features a proton relative process. This suggests that both complex $\mathbf{1}$ and complex $\mathbf{2}$ species can combine with protons and be active toward electrocatalytic $\mathrm{H}_{2}$ production, but the reactivity of the later is stronger than the former.

[Fig. 4 inserted here]

Inspired by DuBois group's work [21,22,23], we also tried to explore the catalytic hydrogen evolution in aqueous media, a much more attractive medium for the sustainable generation of hydrogen. Cyclic voltammetry was carried out in the presence of water in $\mathrm{CH}_{3} \mathrm{CN}$. As shown in Fig. 
5 , following the addition of water to the solution, an increase in the peak current at $-1.26 \mathrm{~V}$ was observed and no positive or negative shift, typical for the reduction of $\mathrm{Fe}^{\mathrm{I}} \mathrm{Fe}^{\mathrm{I}}$ to $\mathrm{Fe}^{0} \mathrm{Fe}^{0}$, indicating complex 1 displayed the catalytic function in water for $\mathrm{H}_{2}$ formation. The new ligand motif that a pyridine ligand is coordinated to a $\mathrm{Fe}^{\mathrm{I}}$ centre, and can be related to water-soluble hydrogenases complexes for further functional studies, with an emphasis on efficient and clean energy utilization way.

\section{[Fig. 5 inserted here]}

\section{Conclusions}

In summary, we successfully prepared a new pyridine substituted [2Fe2S] model complex 1 fully characterized by spectroscopic methods and single-crystal structure analysis. During the investigation of the electrochemical properties in $\mathrm{CH}_{3} \mathrm{CN}$, complex $\mathbf{1}$ is more stable than the previously amine-coordinated iron hydrogenase active site model complex and replacement of pyridine ligand with solvent molecule is slower. Complex 1 was observed to catalyze hydrogen evolution from HOAc and aqueous media at $-1.26 \mathrm{~V}$. The results reported in this work further demonstrate that the low binding strength of a ligand how to affect the stability of a [2Fe2S] model complex, which could mimic the function of the flexible coordination site in the $\mathrm{H}_{2}$ ase enzymes. Those will be of relevance to the natural system. Comparison of the data could help us to develop more efficient catalyst systems by using earth abundant metal ions in the future.

\section{Acknowledgements}

We are grateful to the National Science Foundation of China(21276187), Tianjin Science and Technology Innovation Platform Program(14TXGCCX00017), and the Tianjin Municipal Natural Science Foundation(16JCYBJC20800) for financial support of this work.

\section{Appendix A. Supplementary data}


CCDC 1410968 contains the supplementary crystallographic data for this paper. This data can be obtained free of charge via http://www.ccdc.cam.ac.uk/conts/retrieving.html. Supplementary data related to this article can be found at http:// 


\section{References}

[1] Peters JW, Lanzilotta WN, Lemon BJ, Seefeldt LC. X-ray crystal structure of the Fe-only hydrogenase( $\mathrm{CpI}$ ) from Clostridium pasteurianum to 1.8 angstrom resolution. Science 1998; 282: $1853-1858$.

[2] Morvan D, Capon JF, Gloaguen F, Pétillon FY, Schollhammer P, Talarmin J, Michaud F, Kervarec N. Modeling[FeFe] hydrogenase: Synthesis and protonation of a diiron dithiolate complex containing a phosphine-N-heterocyclic-carbene ligand. Journal of Organometallic Chemistry 2009; 694: 2801-2807.

[3] Wang Z, Jiang W, Liu J, Jiang W, Wang Y, Åkermark B, Sun L. Pendant bases as proton transfer relays in diiron dithiolate complexes inspired by $[\mathrm{Fe}-\mathrm{Fe}]$ hydrogenase active site. Journal of Organometallic Chemistry 2008; 693: 2828-2834.

[4] Liu T, Li B, Popescu CV, Bilko A, Perez LM, Hall MB, Darensbourg MY. Analysis of a pentacoordinate iron dicarbonyl as synthetic analogue of the Hmd or mono-iron hydrogenase active site. Chemistry-A European Journal 2010; 16: 3083-3089.

[5] Song LC, Zhao PH, Du ZQ, Tang MY. Unexpected synthesis of tetrahedral Fe/S clusters via highly reactive butterfly intermediates $(\mu-\mathrm{HS})_{2} \mathrm{Fe}_{2}(\mathrm{CO})_{5}\left[\mathrm{RP}\left(\mathrm{CH}_{2} \mathrm{OH}\right)_{2}\right]$. Organometallics 2010; 29: 5751-5753.

[6] Duan L, Wang M, Li P, Na Y, Wang N, Sun L. Carbene-pyridine chelating 2Fe2S hydrogenase model complexes as highly active catalysts for the electrochemical reduction of protons from weak acid(HOAc). Dalton Transactions 2007; 13: 1277-1283.

[7] Schwartz L, Ekström J, Lomoth R, Ott S. Dynamic ligation at the first amine-coordinated iron hydrogenase active site mimic. Chemical Communications 2006; 40: 4206-4208. 
[8] Wang X, Zhang T, Yang Q, Jiang S, Li B. Synthesis and characterization of bio-inspired diiron complexes and their catalytic activity for direct hydroxylation of aromatic compounds. European Journal of Inorganic Chemistry 2015; 5: 817-825.

[9] Sheldrick G M. SHELXS-97, Program for crystal structure solution; Göttingen, Germany: University of Göttingen: 1997.

[10] Zhang Y, Hu M Q, Wen H M, Si Y, Ma C, Chen C, Liu Q. Terminal pyridine-N ligation at [FeFe]hydrogenase active-site mimic. Journal of Organometallic Chemistry 2009; 694: 2576-2580.

[11] Feng YN, Xu FF, Chen RP, Wen N, Li Z, Du S. Preparation, structures and electrochemical property of diiron dithiolate complexes with hydrophilic N-donor ligands. Journal of Organometallic Chemistry 2012; 717: 211-217.

[12] Goff AL, Artero V, Metayé R, Moggia F, Jousselme B, Razavet M, Tran PD, Palacin S, Fontecave M. Immobilization of FeFe hydrogenase mimics onto carbon and gold electrodes by controlled aryldiazonium salt reduction: An electrochemical, XPS and ATR-IR study. International Journal of Hydrogen Energy 2010; 35: 10790-10796.

[13] Zhao J,Wei Z,Zeng X, Liu X. Three diiron complexes bearing an aromatic ring as mimics of the diiron subunit of [FeFe]-hydrogenase: Synthesis, electron transfer and coupled chemical reactions. Dalton Transactions 2012; 41: 11125-11133.

[14] Wang Y, Zhang T, Li B, Jiang S, Sheng L. Synthesis, characterization, electrochemical properties and catalytic reactivity of $N$-heterocyclic carbene-containing diiron complexes. RSC Advances 2015; 5: 29022-29031.

[15] Chen L, Wang M, Gloaguen F, Zheng D, Zhang P, Sun L. Tetranuclear iron complexes bearing benzenetetrathiolate bridges as four-electron transformation templates and their electrocatalytic properties for proton reduction. Inorganic Chemistry 2013; 52: 1798-1806. 
[16] Orain PY, Capon JF, Gloaguen F, Schollhammer P, Talarmin J. Tuning of electron transfer in diiron azo-bridged complexes relevant to hydrogenases. International Journal of Hydrogen Energy 2010; 35: 10797-10802.

[17] Song LC, Yang ZY, Bian HZ, Liu Y, Wang H, Liu XF, Hu QM. Diiron oxadithiolate type models for the active site of iron-only hydrogenases and biomimetic hydrogen evolution catalyzed by $\mathrm{Fe}_{2}\left(\mu-\mathrm{SCH}_{2} \mathrm{OCH}_{2} \mathrm{~S}-\mu\right)(\mathrm{CO})_{6}$. Organometallics $2005 ; 24$ : 6126-6135.

[18] Mejia-Rodriguez R, Chong D, Reibenspies JH, Soriaga MP, Darensbourg MY. The hydrophilic phosphatriazaadamantane ligand in the development of $\mathrm{H}_{2}$ production electrocatalysts: Iron hydrogenase model complexes. Journal of the American Chemical Society 2004; 126(38): 12004-12014.

[19] Chong D, Georgakaki IP, Mejia-Rodriguez R, Sanabria-Chinchilla J, Soriaga MP, Darensbourg MY. Electrocatalysis of hydrogen production by active site analogues of the iron hydrogenase enzyme: Structure/function relationships. Dalton Transactions 2003; 21: 4158-4163.

[20] Capon JF, El Hassnaoui S, Gloaguen F, Schollhammer P, Talarmin J. N-Heterocyclic carbene ligands as cyanide mimics in diiron models of the all-iron hydrogenase active site. Organometallics 2005; 24: 2020-2022.

[21] Helm ML, Stewart MP, Bullock RM, DuBois DL. A synthetic nickel electrocatalyst with a turnover frequency above $100,000 \mathrm{~s}^{-1}$ for $\mathrm{H}_{2}$ production. Science 2011; 333: 863-866.

[22] Kilgore UJ, Roberts JAS, Pool DH, Appel AM, Stewart MP, DuBois MR, Dougherty WG, Kassel WS, Bullock RM, DuBois DL. $\left[\mathrm{Ni}\left(\mathrm{PPh}_{2} \mathrm{NC}_{6} \mathrm{H}_{4} \mathrm{X}_{2}\right)_{2}\right]^{2+}$ Complexes as electrocatalysts for $\mathrm{H}_{2}$ production: Effect of substituents, acids, and water on catalytic rates. Journal of the American Chemical Society 2011; 133: 5861-5872. 
[23] Cao JP, Fang T, Fu LZ, Zhou LL, Zhan SZ. First mononuclear copper(II) electro-catalyst for catalyzing hydrogen evolution from acetic acid and water. International Journal of Hydrogen Energy 2014; 39: 13972-13978.

\section{Captions to Scheme and Figures}

Scheme 1 The synthesis of the complexes 1 and $\mathbf{2}$

Fig. 1 X-ray crystal structure of complex $\mathbf{1}$ (ellipsoids at $30 \%$ probability level). The hydrogen atoms are omitted for clarity.

Fig. 2 Cyclic voltammogram of complex $1(1.0 \mathrm{mM})$ in $0.1 \mathrm{M} n-\mathrm{Bu}_{4} \mathrm{NPF}_{6} / \mathrm{MeCN}$. Under $\mathrm{CO}$ atmosphere(A), under $\mathrm{N}_{2} 5 \min (\mathrm{B})$, under $\mathrm{N}_{2} 2 \mathrm{~h}(\mathrm{C})$, in the presence of excess pyridine under $\mathrm{CO}$ 
atmosphere(D) ; scan rate, $100 \mathrm{mV} / \mathrm{s}$.

Fig. 3 IR spectral changes for complex 1 following various conditions and time in $0.1 \mathrm{M} n$ $\mathrm{Bu}_{4} \mathrm{NPF}_{6} / \mathrm{MeCN}$. A(under $\mathrm{CO}$ atmosphere), $\mathrm{B}\left(\right.$ under $\mathrm{N}_{2} 5 \mathrm{~min}$ ), $\mathrm{C}\left(\right.$ under $\mathrm{N}_{2} 2 \mathrm{~h}$ ), $\mathrm{D}$ (in the presence of excess pyridine under $\mathrm{CO}$ atmosphere), respectively.

Fig. 4 Cyclic voltammograms of the complex $1(1 \mathrm{mM})$ and with $\operatorname{HOAc}(0,1,2,4,6$ and $8 \mathrm{mmol})$ in $\mathrm{CH}_{3} \mathrm{CN}$ solution $\left(0.1 \mathrm{M} n-\mathrm{Bu}_{4} \mathrm{NPF}_{6}\right)$ under $\mathrm{N}_{2}$ at room temperature; scan rate, $100 \mathrm{mV} / \mathrm{s}$.

Fig. 5 Cyclic voltammograms of complex $1(1 \mathrm{mM})$ detailing the effect of $\mathrm{H}_{2} \mathrm{O}$ on the catalytic proton reduction in $\mathrm{CH}_{3} \mathrm{CN}$ solution $\left(0.1 \mathrm{M} n-\mathrm{Bu}_{4} \mathrm{NPF}_{6}\right)$ under $\mathrm{N}_{2}$ at room temperature; scan rate, $100 \mathrm{mV} / \mathrm{s}$.

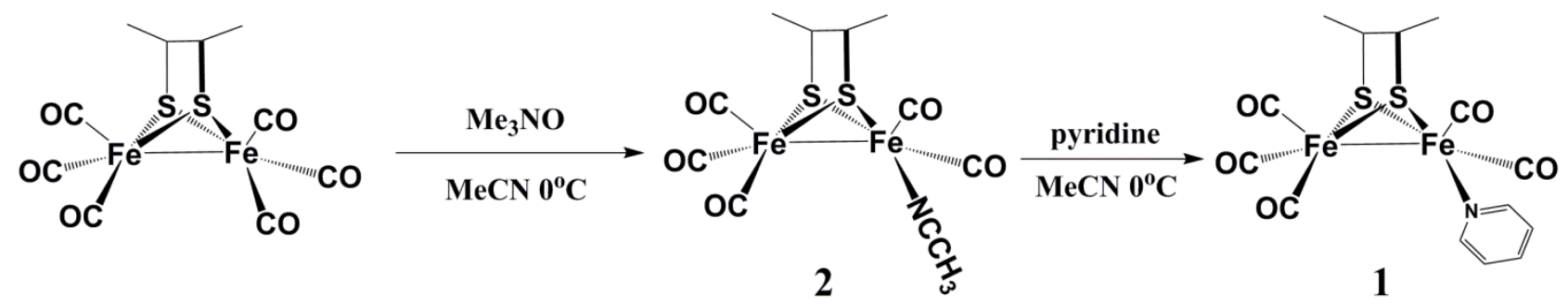

Scheme 1 The synthesis of the complexes 1 and 2 


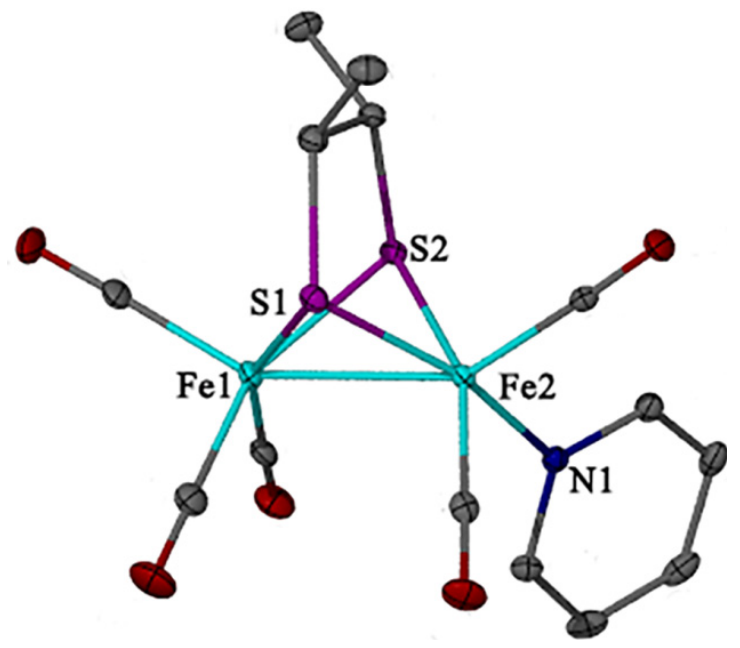

Fig. 1 X-ray crystal structure of complex $\mathbf{1}($ ellipsoids at $30 \%$ probability level). The hydrogen atoms are omitted for clarity. 

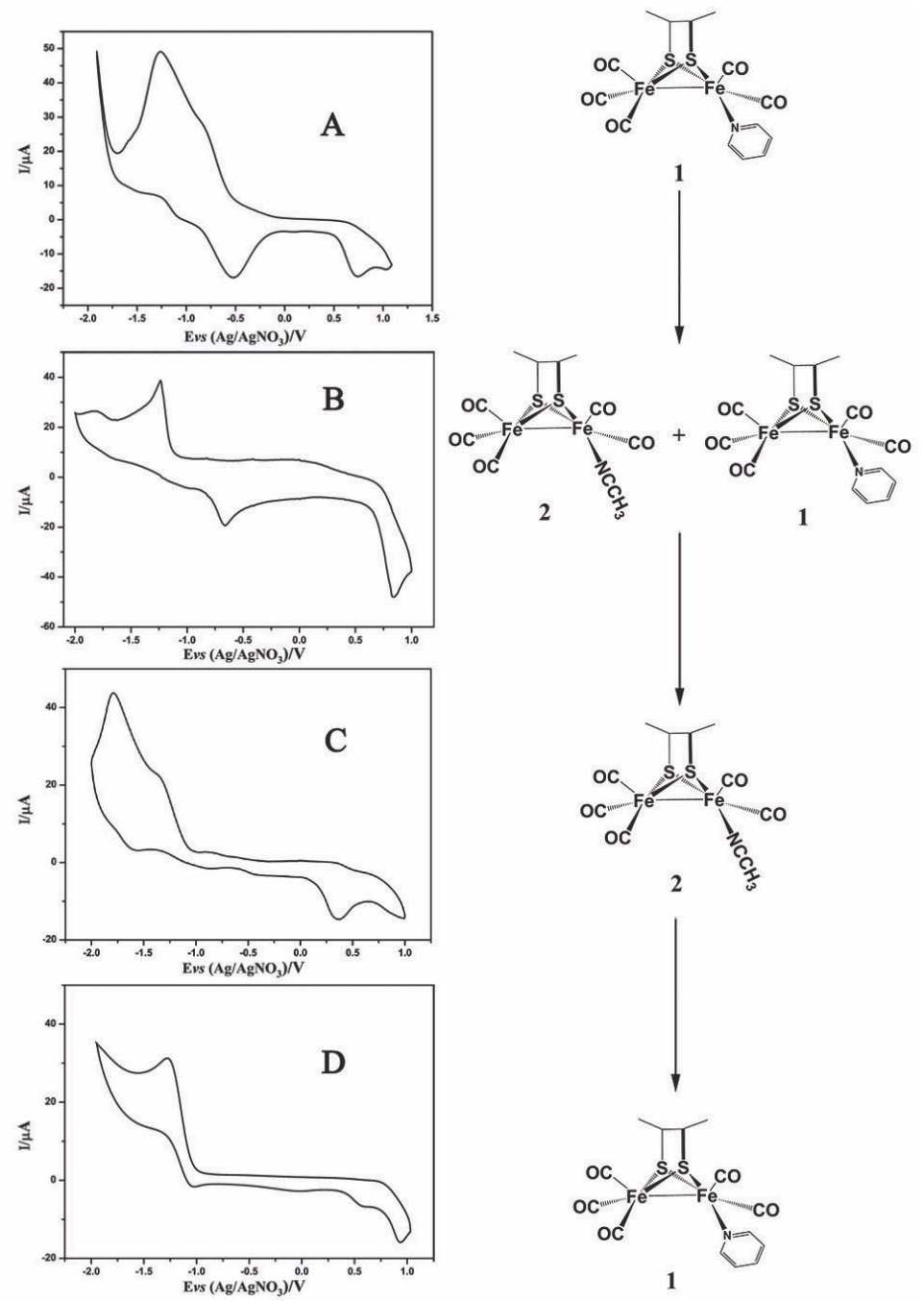

Fig. 2 Cyclic voltammogram of complex $1(1.0 \mathrm{mM})$ in $0.1 \mathrm{M} n$-Bu $\mathrm{Bu}_{4} \mathrm{NF}_{6} / \mathrm{MeCN}$. Under $\mathrm{CO}$ atmosphere(A), under $\mathrm{N}_{2} 5 \min (\mathrm{B})$, under $\mathrm{N}_{2} 2 \mathrm{~h}(\mathrm{C})$, in the presence of excess pyridine and $\mathrm{CO}$ atmosphere(D); scan rate, $100 \mathrm{mV} / \mathrm{s}$. 


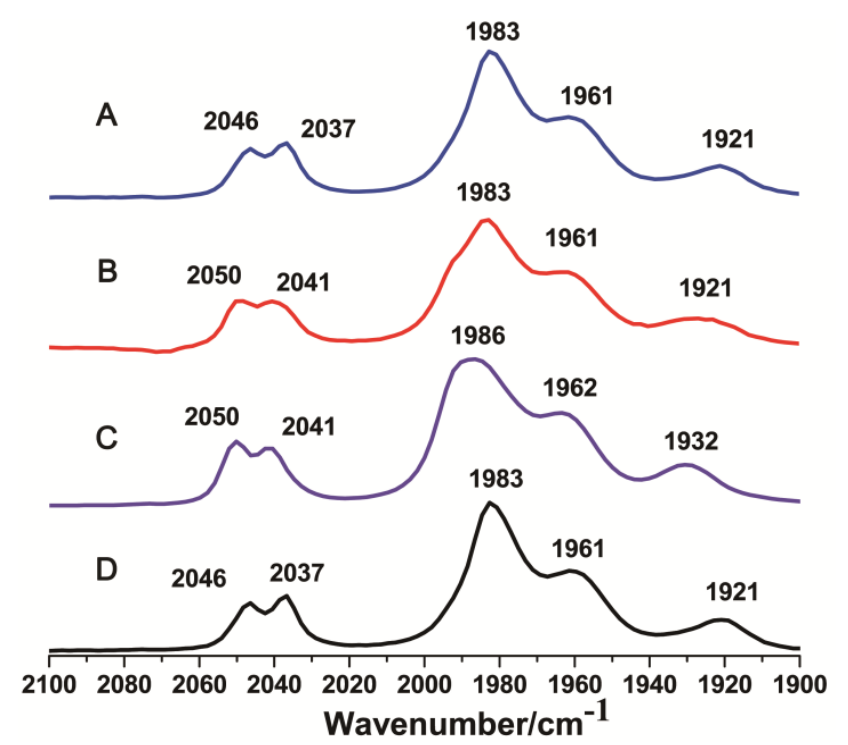

Fig. 3 IR spectral changes for complex 1 following various conditions and time in $0.1 \mathrm{M} \mathrm{n}$ $\mathrm{Bu}_{4} \mathrm{NPF}_{6} / \mathrm{MeCN}, \mathrm{A}$ (under $\mathrm{CO}$ atmosphere), $\mathrm{B}$ (under $\mathrm{N}_{2} 5$ min), $\mathrm{C}$ (under $\mathrm{N}_{2} 2$ h), $\mathrm{D}$ (in the presence of excess pyridine and $\mathrm{CO}$ atmosphere), respectively.

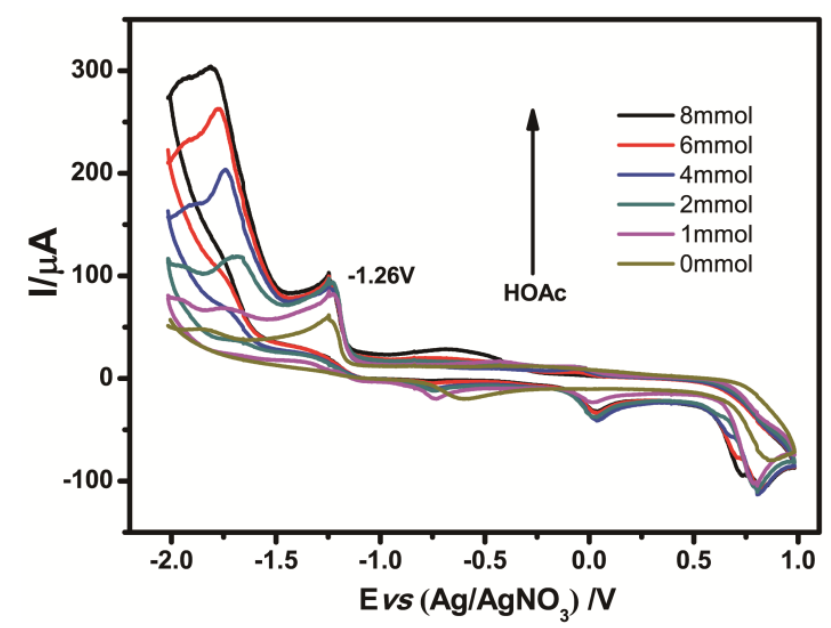

Fig. 4 Cyclic voltammograms of the complex $1(1 \mathrm{mM})$ and with $\operatorname{HOAc}(0,1,2,4,6$ and $8 \mathrm{mmol})$ in $\mathrm{CH}_{3} \mathrm{CN}$ solution $\left(0.1 \mathrm{M} n\right.$ - $\left.\mathrm{Bu}_{4} \mathrm{NPF}_{6}\right)$ under $\mathrm{N}_{2}$ at room temperature; scan rate, $100 \mathrm{mV} / \mathrm{s}$. 


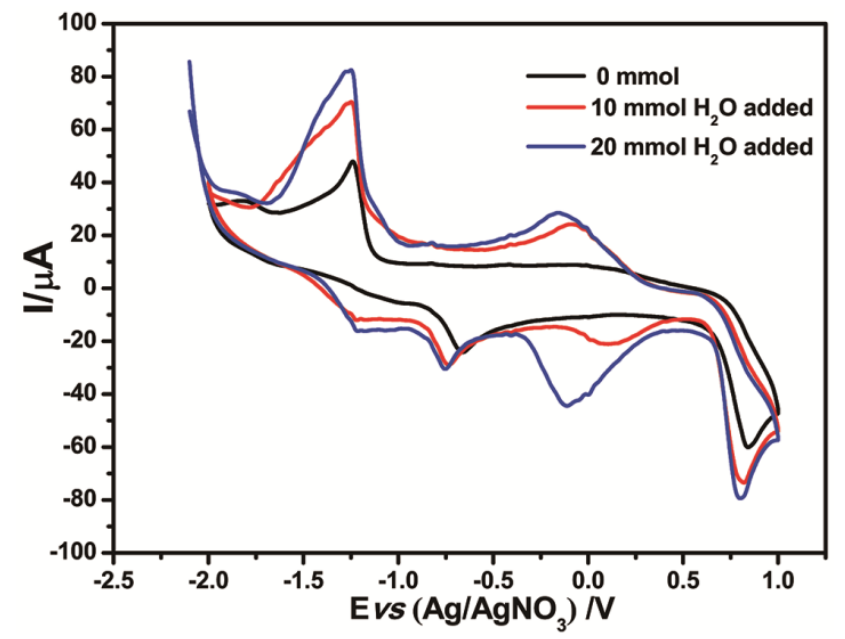

Fig. 5 Cyclic voltammograms of complex $1(1 \mathrm{mM})$ detailing the effect of $\mathrm{H}_{2} \mathrm{O}$ on the catalytic proton reduction in $\mathrm{CH}_{3} \mathrm{CN}$ solution $\left(0.1 \mathrm{M} n-\mathrm{Bu}_{4} \mathrm{NPF}_{6}\right)$ under $\mathrm{N}_{2}$ at room temperature; scan rate, $100 \mathrm{mV} / \mathrm{s}$. 